\title{
GRANd Teton NATional PARK FOCUSED VISITOR SURVEY
}

\author{
PAT STEPHENS WILLIAMS $\uparrow$ RAY DARVILLE $\uparrow$ MICHAEL LEGG \\ ARTHUR TEMPLE COLLEGE OF FORESTRY AND AGRICULTURE \\ STEPHEN F. AUSTIN STATE UniVERSITY $\uparrow$ NACOGDOCHES, TEXAS
}

\begin{abstract}
$\uparrow \quad$ AbSTRACT
In the summer of 2010 research was conducted in Grand Teton National Park to ascertain trip characteristics of GRTE visitors, examine pertinent socio-demographic visitor characteristics, develop an understanding of how visitor sociodemographics affect trip characteristics and outcomes, and determine how these characteristics and demographics affect interest in and experiences with the Indian Arts Museum. Researchers spent seven weeks in the park and followed the onsite data gathering with an at home follow-up for visitors.
\end{abstract}

\section{$\downarrow \quad$ INTRODUCTION}

During spring, 2010, the researchers contracted with the Grand Teton Association (GTA) to conduct a visitors' study in the Moose and Colter Bay areas of Grand Teton National Park (GRTE) during the summer, 2010 season. Research objectives were identified and the methodology designed in cooperation with GTA and GRTE. The research called for an on-site survey at Moose and Colter Bay as well as an at-home survey for visitors to complete after their trip to the Park. The results of the at home and on site surveys have been combined where possible. Otherwise, results are organized by the location of the data collection (Colter Bay, Moose, and at home), which will allow the reader to focus on visitors in the specific areas of interest. Furthermore, reporting of the results has the aim of addressing the research objectives, which will assist the park managers and others to answer questions regarding visitors' experiences in GRTE.

\section{$\downarrow \quad$ RESEARCH OBJECTIVES}

1. To examine pertinent sociodemographic visitor characteristics.

2. To ascertain trip characteristics of GRTE visitors:

- Purpose for trip, including destination determination.

- Trip length and time for trip.

- Trip expectations.

- Trip activities and events.

- Trip services expected and utilized.

- Pre-trip planning and information sources.

- Pre-existing knowledge of and expectations about the area and potential experience.

- Expectations and utilization of specific sites including the Colter Bay Visitor Center and the Indian Arts Museum Vernon Collection.

- Expectations, anticipated results and preferences concerning relocation of specifically identified facilities.

3. To develop an understanding of how visitor socio-demographics affect trip characteristics and outcomes. 


\section{METHODS}

During spring, 2010 the research team contracted with the Grand Teton Association to provide a social survey of Grant Teton National Park visitors during the summer, 2010 season. Survey instruments were developed in cooperation with National Park Service (NPS) employees; instruments were designed to elicit information to answer research questions and to meet the research objectives of the project.

The study design included three separate survey instruments and one interview instrument: 1) On-site interview/survey at Colter Bay and Moose, 2) At-home survey, and 3) the Indian Arts Museum Interview. The At-home Survey was self-administered by visitors after returning home through Survey Monkey, an Internet-based survey program.

First, to obtain information and addresses for the at home survey, visitors were stopped at a location across from the General Store at Colter Bay, asked a small set of questions about their trip and were asked to participate in an at-home survey after they returned home. This brief interview and solicitation took about 3 minutes to complete. The goal was to collect a minimum of 1,500 participants for the at-home survey. This goal was met.

Second, research assistants conducted the On-site Interview at Colter Bay and Moose by soliciting voluntary personal interviews of visitors at two locations: 1) across from the General Store at Colter Bay and 2) outside Moose Visitor Center. Respondents were approached about participating as they were exiting the parking lot at Colter Bay and exiting the visitor center at Moose. Respondents at both locations were asked parallel questions. The interview took about eight minutes to complete. Researchers had established a goal of a minimum of 300 interviews with about two-thirds coming from Colter Bay, where the Indian Arts Museum is located, and one-third from the Moose area. These proportions were maintained and reflected in the data.

Third, a brief Museum Interview of fourquestions was administered to willing visitors immediately upon their exit from the Visitor Center Colter Bay. These questions were open-ended with the objective of providing additional, detailed information, especially about their experience at the Visitor Center and Indian Arts Museum.

In addition to the on-site surveys and interviews, a traffic counter was used at the exit to
Colter Bay near the General Store to track approximate traffic totals during the on-site survey period.

Fourth, the At-home Survey was administered during fall, 2010. All respondents with legitimate email addresses were sent an invitation to participate in the self-administered survey through Survey Monkey. Researchers sent the initial invitation and then sent three follow-up reminders to participate over a four-week period. The survey consisted of over 40 questions which duplicated most of those asked onsite as well as additional questions regarding recreational experiences. The goal to obtain a 50 percent response rate was met.

\section{Survey Solicitation}

During June, July, and August, two research assistants participated in research activities at Colter Bay and Moose. Researchers spent two-thirds of their time at Colter Bay and one-third of their time at Moose. This time was allocated based on research objectives.

The interviewers were stationed across from the General Store on the exit lane of the drive. One large road sign stating the presence of a traffic survey was posted at the intersection across from the restaurant. Another sign was posted on the road immediately before the survey area. As vehicles stopped for the traffic stop, a researcher approached the stopped vehicle. A brief script was read, informing the driver of the survey and asking the driver to participate in the survey. If the driver agreed to participate in the At-Home Survey, the driver completed the contact information form that included their name, mailing address, and email address. Then, the driver was asked three brief questions. The driver then departed the traffic stop area. Because of traffic congestion concerns identified by park officials, the research assistants stopped no more than three vehicles at one time. Thus, if three vehicles were stopped, other approaching vehicle or vehicles were waived past the traffic stop. Individuals who had participated already in a prior stop were also waived past. Tour buses were excluded from the study as were NPS and business vehicles.

Individuals were free to refuse to participate in the research project. About four percent of the total traffic count as measured by the traffic counters refused to participate in the study.

\section{RESULTS}




\section{Key Points:}

Overall, the results of the three different surveys are similar. Based on previous studies and experience, the demographic characteristics contain no surprises. The respondents were well educated, about half were traveling with children. About half were repeat visitors to GRTE. Half were between 40 and 60 years of age. About $20 \%$ were day visitors and $80 \%$ were planning to stay overnight in the park.

- In the Museum, the bead and wardrobe exhibits were listed as the most important, ranking higher than all of the other exhibits combined. The moccasin exhibit was the next most important.

- Of the Colter Bay respondents ( $\mathrm{N}=163), 38 \%$ of those visiting the museum said they were less likely to visit the museum if moved to Moose, while $53 \%$ indicated they were not sure or that it would make no difference in their likelihood of visiting the Museum. Of the Moose respondents $(\mathrm{N}=56), 82 \%$ said they would be likely to visit the museum if it was located at Moose and about half of the respondents had visited the museum. Of the At-Home Survey respondents ( $\mathrm{N}=540$ ), 26\% said they were less likely to visit at Moose while $12 \%$ said they were more likely to visit and $72 \%$ said they were not sure.

- The participants in this study indicate that wildlife and nature are primary interests. Regardless of the location of the Museum, a natural history relationship established with the cultural objects displayed may significantly increase visitation.

\section{Selected Results of Interest:}

- Of the services and facilities used at Colter Bay, the General Store was ranked first in the degree to which respondents liked services and facilities at Colter Bay. The showers and Visitor Center came in second with $28 \%$ of respondents identifying these facilities.

- Of the recreational activities used at the Colter Bay, the museum ranked $10^{\text {th }}$.

- $39 \%$ said they were aware of the Indian Arts Museum before the trip began; being aware of the Museum before the trip began did not increase the likelihood that they visited the Museum.
- The typical respondent indicated being in the Museum between 30 minutes and one hour while about a third of respondents said they were in the Museum for one hour or longer

- Fifty-one percent of the At-Home Survey indicated they visited the Museum. Women were slightly more likely than men to visit the Museum. Individuals in their 40 s or older were significantly more likely to visit the Museum than those in their $20 \mathrm{~s}$ and $30 \mathrm{~s}$. Education was not significantly related to visiting though those with a high school education or less were the most likely $(59 \%)$ to visit. Those who went to the Museum had a slightly lower party size and lower number of family members than those who did not visit the museum. Those visiting the park for the first time were slightly more likely to visit the Museum, as were those staying longer in the park and those entering through the East entrance.

- Visitors to the Museum placed a higher importance than those that did not visit on these five activities out of nineteen: non-motorized boating, museum, visitor center, horseback riding, and ranger programs.

- Almost $80 \%$ of those attending at least one ranger program at Colter Bay visited the Museum while only $44 \%$ of those not attending a ranger program visited the Museum.

- About $83 \%$ of Colter Bay visitors visited the Colter Bay Visitor Center.

- Services used at Colter Bay indicated the most important was restrooms at $76 \%$, followed closely by $71 \%$ using the information counter, and $55 \%$ using the bookstore.

\section{Traffic Counts}

Upon exiting the survey area, vehicles passed through an infrared traffic counter. Results of the traffic counts are in Table 1 below. In eight 6-hour sampling periods, over 7,000 traffic counts were recorded, yielding about 930 vehicles per time period or about 155 vehicles per hour.

\section{Tour Buses}

Between June 29 and August 4 of the data collection time period, the research assistants 
identified by name and counted the number of tour buses leaving the Colter Bay area on thirteen days of the sampling time framework. Results show that 32 tour buses were counted, an average of 2.5 per day (Table 2). Over a 90-day summer period, the number of buses was estimated to be 225. Assuming an average of 40 visitors per bus, one could estimate that well over 9,000 bus visitors went through the Colter Bay area each summer. Due to time constraints for the tours, the buses were not stopped at the Colter Bay traffic stop nor were any individuals travelling on buses interviewed.

Table 1. Traffic counts during sampling period.

\begin{tabular}{|l|l|l|}
\hline Date & Count & Time Period \\
\hline $7 / 8 / 2010$ & 934 & $9: 00 \mathrm{am}-3: 00 \mathrm{pm}$ \\
\hline $7 / 12 / 2010$ & 878 & $9: 00 \mathrm{am}-3: 00 \mathrm{pm}$ \\
\hline $7 / 28 / 2010$ & 964 & $9: 00 \mathrm{am}-3: 00 \mathrm{pm}$ \\
\hline $7 / 29 / 2010$ & 947 & $1: 00 \mathrm{pm}-7: 00 \mathrm{pm}$ \\
\hline $7 / 30 / 2010$ & 933 & $9: 00 \mathrm{am}-3: 00 \mathrm{pm}$ \\
\hline $8 / 1 / 2010$ & 921 & $1: 00 \mathrm{pm}-7: 00 \mathrm{pm}$ \\
\hline $8 / 4 / 2010$ & 953 & $9: 00 \mathrm{am}-3: 00 \mathrm{pm}$ \\
\hline $8 / 6 / 2010$ & 922 & $1: 00 \mathrm{pm}-7: 00 \mathrm{pm}$ \\
\hline Total & 7,452 & \\
\hline Mean & 931.5 & \\
\hline
\end{tabular}

\section{Survey Results Characteristics of Colter Bay Visitors}

The characteristics of the respondents (Table 3) are based upon 871 completed surveys either at home or in the Colter Bay parking area. The characteristics should be representative of the generalized visitor to Colter Bay with the exception of the gender data. A larger than expected proportion of the respondents was male. This is due to the preponderance of males in the interviews conducted on-site at Colter Bay. Because the interviewers approached the driver's side of the vehicle, males were interviewed disproportionately as compared to females. However, the remainder of the data should be representative of the generalized visitor.

The visitors were predominantly white with only $15 \%$ indicating a race other than Caucasian. As expected the visitors were well educated with $80 \%$ having completed a Bachelor or Graduate degree. Only $4 \%$ had a high school or less education. Approximately $70 \%$ of the parties surveyed had children present with a mean of 2.6 children in those parties having children present in the Park. For all groups surveyed, the mean group size was 3.4 members. However, the median was 2.0 indicating that half of the respondents had no more than 2 people in their group.

Approximately $56 \%$ of the respondents had made one or more previous trips to GRTE with $44 \%$ being on their first trip to the park. The median number of previous trips was one, indicating that about half of the visitors had only one previous trip to the Park. The mean was 4.6 previous trips suggesting that many were experienced visitors with numerous trips to the area. The results seem to indicate three types of visitors related to experience. About $45 \%$ are first time visitors while about 30 percent are on their second trip to the area and about $25 \%$ have made several previous trips to the park.

Table 2. Tour buses at Colter Bay.

\begin{tabular}{|c|c|c|}
\hline Number & Date & Name \\
\hline 1 & $6 / 29 / 2010$ & Green Tortoise \\
\hline 2 & $7 / 2 / 2010$ & West Valley Charter \\
\hline 3 & & Holiday Motor Coach \\
\hline 4 & $7 / 5 / 2010$ & Lamoille Valley Bus \\
\hline 5 & $7 / 8 / 2010$ & Lewis Stage \\
\hline 6 & $7 / 9 / 2010$ & Lake Shore Motor Coach \\
\hline 7 & & $\begin{array}{lll}\begin{array}{l}\text { Yellowstone } \\
\text { yellow bus) }\end{array} & \text { Tours } & \text { (old } \\
\end{array}$ \\
\hline 8 & $7 / 12 / 2010$ & Arrow Stage Line \\
\hline 9 & & Lamoille Valley Bus \\
\hline 10,11 & & OC\&W Coachways ( 2 buses) \\
\hline 12 & $7 / 13 / 2010$ & Lewis Stage \\
\hline 13 & $7 / 15 / 2010$ & Lake Shore Motor Coach \\
\hline 14 & & Lewis Stage \\
\hline 15 & & Lin Lines \\
\hline 16 & $7 / 25 / 2010$ & Arrow Stage Line \\
\hline 17 & & Lamoille Valley Bus \\
\hline 18 & & Le Bus \\
\hline 19 & & $\begin{array}{l}\begin{array}{l}\text { Yellowstone } \\
\text { silver bus) }\end{array} \\
\text { sours }\end{array}$ \\
\hline 20 & $7 / 28 / 2010$ & MTR Western \\
\hline 21 & & Capital \\
\hline 22 & & Holiday Motor Coach \\
\hline$\frac{23}{23}$ & $7 / 30 / 2010$ & Lake Shore Motor Coach \\
\hline 24 & & $\begin{array}{l}\begin{array}{l}\text { Yellowstone } \\
\text { yellow bus) }\end{array} \\
\text { Tours } \quad \text { (old }\end{array}$ \\
\hline 25 & $8 / 1 / 2010$ & Holiday Motor Coach \\
\hline 26 & & Utah Trailways \\
\hline 27 & $8 / 4 / 2010$ & Smith Coachways \\
\hline 28,29 & & $\begin{array}{l}\text { Holiday Motor Coach } \\
\text { buses) }\end{array}$ \\
\hline 30 & & Lake Shore Motor Coach \\
\hline 31 & & Yellowstone (old yellow bus) \\
\hline 32 & & Fabulous Coach Lines \\
\hline
\end{tabular}

Table 3. Demographic characteristics of respondents based upon the combined data from on-site and at home surveys. 


\section{Trip Characteristics}

\begin{tabular}{|c|c|c|c|c|c|}
\hline 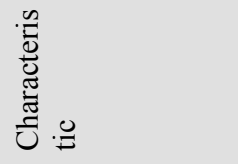 & 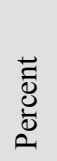 & $\stackrel{\varpi}{\Sigma}^{\Xi}$ & 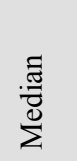 & 䒠 & 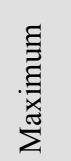 \\
\hline \multicolumn{6}{|l|}{ Gender } \\
\hline Male & 62 & & & & \\
\hline Female & 38 & & & & \\
\hline \multicolumn{6}{|l|}{ Race } \\
\hline Non-White & 15 & & & & \\
\hline White & 85 & & & & \\
\hline \multicolumn{6}{|l|}{ Education } \\
\hline $\begin{array}{l}\text { High School or } \\
\text { Less }\end{array}$ & 4 & & & & \\
\hline Some College & 16 & & & & \\
\hline Bachelor Degree & 34 & & & & \\
\hline Graduate Degree & 46 & & & & \\
\hline Children & 70 & 2.6 & & 0 & 7 \\
\hline Age $0-12$ & 69 & 1.7 & & 0 & 4 \\
\hline Age 13-18 & 70 & 1.5 & & 0 & 4 \\
\hline Age & & 48.7 & 49.0 & 18 & 82 \\
\hline Party Size & & 3.4 & 2.0 & 1 & 30 \\
\hline $\begin{array}{l}\text { Previous Trips } \\
\text { to GRTE }\end{array}$ & & 4.6 & 1.0 & 0 & 100 \\
\hline
\end{tabular}

The generalized characteristics of survey participants' trip to GRTE and Colter Bay are described in Table 4. The characteristics are based upon the merged data from on-site interviews at Colter Bay and the at home surveys. Over $75 \%$ of the visitors were planning to stay overnight in the Park with the median length of stay being four days and the mean was 4.9 days. Those spending one or more nights in the Park were asked what type of lodging they were using. The plurality of respondents $(41 \%)$ were either staying in a tent or camping. Significantly, another $23 \%$ indicated that they were in some type of RV or camper trailer. A total of $30 \%$ were staying in a cabin, cottage, or hotel in the Park. Approximately $70 \%$ of the visitors indicated that a location other than GRTE was their most important trip destination. However, among those who had made previous trips to the park $57 \%$ indicated that GRTE was their primary destination. There is a statistically significant relationship between the number of trips and whether GRTE was the primary destination.

Table 4. Generalized Characteristics of respondents based upon the combined data from on-site and at home surveys.

\begin{tabular}{|c|c|c|c|c|c|}
\hline 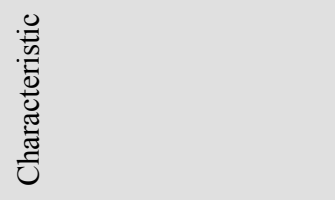 & 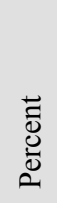 & $\stackrel{\tilde{E}}{\sum^{ \pm}}$ & 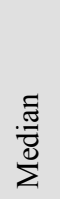 & $\begin{array}{l}\text { 声 } \\
\text { 声 } \\
\end{array}$ & 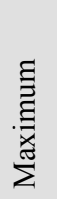 \\
\hline \multicolumn{6}{|l|}{ First Trip to GRTE } \\
\hline No & 56 & & & & \\
\hline Yes & 44 & & & & \\
\hline \multicolumn{6}{|l|}{ Trip Type } \\
\hline Overnight & 76 & & & & \\
\hline Day Only & 24 & & & & \\
\hline Days in the Park & & 4.9 & 4.0 & 1 & 43 \\
\hline \multicolumn{6}{|l|}{$\begin{array}{l}\text { GRTE Most Important } \\
\text { Trip Destination }\end{array}$} \\
\hline No & 70 & & & & \\
\hline Yes & 30 & & & & \\
\hline \multicolumn{6}{|l|}{ Entrance into Park } \\
\hline North & 41 & & & & \\
\hline East & 14 & & & & \\
\hline South & 45 & & & & \\
\hline \multicolumn{6}{|l|}{ Exit from the Park } \\
\hline North & 38 & & & & \\
\hline East & 11 & & & & \\
\hline South & 50 & & & & \\
\hline \multicolumn{6}{|l|}{$\begin{array}{l}\text { Visited Colter Bay on } \\
\text { Trip }\end{array}$} \\
\hline No & 7 & & & & \\
\hline Yes & 93 & & & & \\
\hline \multicolumn{6}{|l|}{$\begin{array}{lcc}\text { Visited } & \text { Colter } & \text { Bay } \\
\text { Visitor Center } & \end{array}$} \\
\hline No & 24 & & & & \\
\hline Yes & 76 & & & & \\
\hline \multicolumn{6}{|l|}{ First Trip to Colter Bay } \\
\hline No & 34 & & & & \\
\hline Yes & 66 & & & & \\
\hline $\begin{array}{l}\text { Previous Visits to Colter } \\
\text { Bay }\end{array}$ & 34 & 8.9 & 3.0 & 0 & 100 \\
\hline
\end{tabular}

Over $90 \%$ of the respondents had visited Colter Bay on this trip to the Tetons. For $66 \%$ it was their first trip to the Colter Bay area. Of the $90 \%$ who stopped at Colter Bay, $76 \%$ went to the Visitor Center. Most who did not visit the Visitor Center during this trip were individuals who had made previous trips to Colter Bay. Approximately $45 \%$ of those staying at Colter Bay indicated it was the most important destination on this trip.

\section{Recreational Activity at Colter Bay}

Respondents were provided a list of 19 recreational activities available to them in the Colter Bay area. Using a five-point scale with 1 being not important to 5 being very important, they were asked to indicate the importance of the activities on their trip. Results show the items in descending mean order; the activities at the top, therefore, are more important than 
others below (Table 5). The top five recreational activities all have means greater than 4 out of 5 on the scale: Observing Wildlife, Observing Nature, Walking, Photography, and Day Hiking. Ranking eight through ten respectively are the Visitor Center, Ranger Program, and the Museum. Observing Wildlife and Observing Nature have relatively small standard deviation values suggesting great amount of consistency of responses; high importance values were consistently given by the respondents. The fact that the Museum, Visitor Center and Ranger Program were ranked close together indicates they were often chosen as a set and ranked similarly. This conclusion is supported by the factor analysis that follows. The high ranking of Observing Wildlife and Observing Nature is consistent with the factor analysis findings also. They seem to be the very most important activities for visitors to Colter Bay.

Table 5. Importance of Recreational Activities

\begin{tabular}{|l|l|l|l|}
\hline $\begin{array}{l}\text { Recreational } \\
\text { Activities }\end{array}$ & N & Mean & $\begin{array}{l}\text { Std. } \\
\text { Deviation }\end{array}$ \\
\hline Observing Wildlife & 497 & 4.74 & .582 \\
\hline Observing Nature & 504 & 4.73 & .627 \\
\hline Walking & 479 & 4.27 & 1.060 \\
\hline Photography & 466 & 4.26 & 1.044 \\
\hline Hiking Day Only & 433 & 4.26 & 1.132 \\
\hline Camping & 419 & 3.83 & 1.519 \\
\hline Picnicking & 408 & 3.61 & 1.286 \\
\hline Visitor Center & 468 & 3.55 & 1.196 \\
\hline Ranger Program & 391 & 3.22 & 1.359 \\
\hline Museum & 446 & 2.98 & 1.285 \\
\hline Cabins & 365 & 2.82 & 1.568 \\
\hline $\begin{array}{l}\text { Non-Motorized } \\
\text { Boating }\end{array}$ & 378 & 2.68 & 1.487 \\
\hline Fishing & 380 & 2.61 & 1.559 \\
\hline Swimming & 380 & 2.57 & 1.398 \\
\hline $\begin{array}{l}\text { Hiking in } \\
\text { Backcountry }\end{array}$ & 367 & 2.50 & 1.520 \\
\hline Bicycling & 374 & 2.50 & 1.395 \\
\hline Horseback Riding & 369 & 2.45 & 1.433 \\
\hline Motorized Boating & 378 & 2.25 & 1.457 \\
\hline Jogging & 365 & 1.97 & 1.356 \\
\hline
\end{tabular}

\section{Recreational Activity Importance-Factor Analysis}

Principal components analysis was used to factor analyze the importance of the 19 recreational activities. Combined, the five factors explained $60.2 \%$ variance. The first factor, Recreational Activity, had four water-related activities with Bicycling. Factor two, Interpretive Services, had three variables loading: Visitor Center, Museum, and Ranger Program. Of note here, the importance rating of all three of these produced significant positive relationships with visiting the Museum. The third factor Nature Study had two variables, Observing Wildlife and Observing Nature. The fourth factor is the Hiking factor, which included: Day Hiking, Walking, and Hiking in the Backcountry. And, the fifth factor was the Importance of Cabins at Colter Bay.

Table 6. Rotated Component Matrix Recreational Activity Importance.

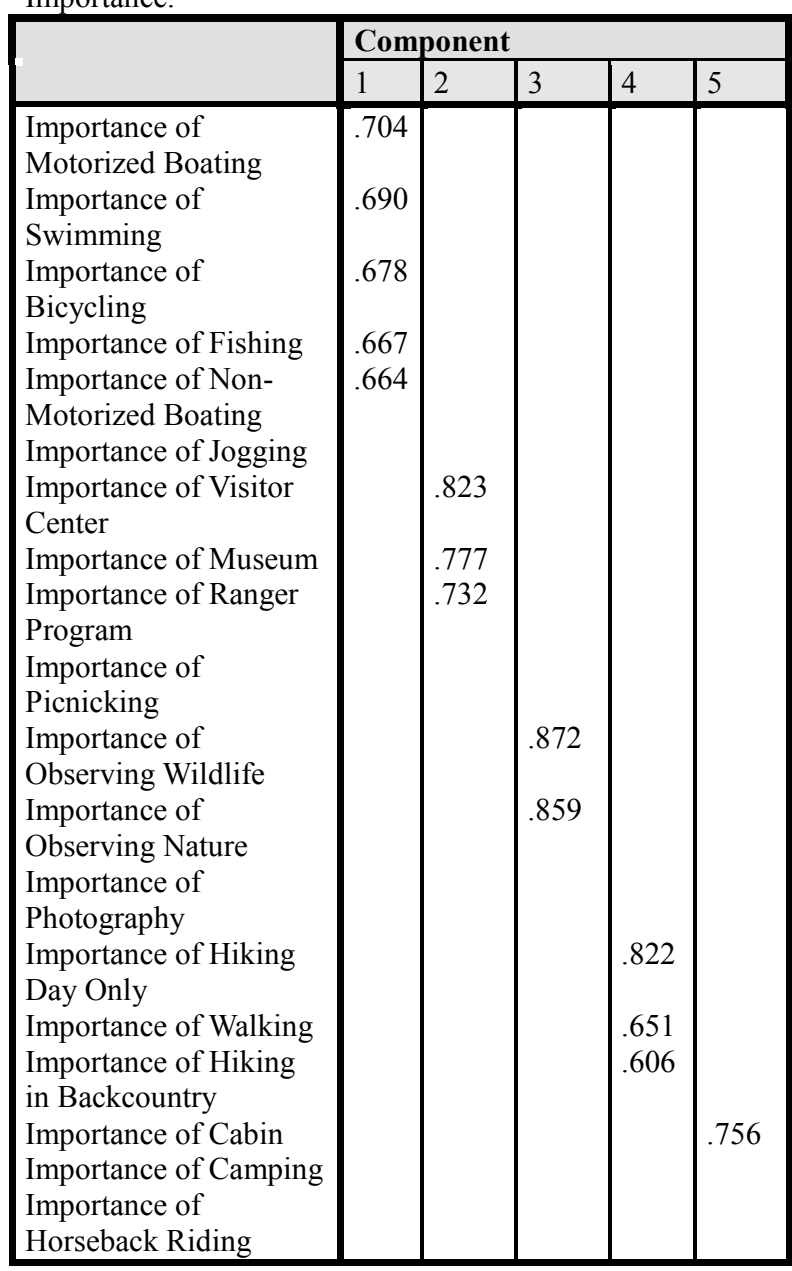

This factor analysis suggests that 4 important market segments visit Colter Bay. There is a water/active recreation group for which the Marina a very important service of the area. There is a segment that is interested in interpretive services that form the core user group of the Museum. There is a group that is interested in hiking or walking the trails in the area and finally there is a group who are primarily interested in seeing wildlife in its natural environment. Each of these segments may utilize numerous facilities and services in Colter Bay, but they are most concerned about the facilities included in their grouping. The median and mean number of services utilized on the trip by each respondent were both 4 . 
Over $90 \%$ of the visitors to Colter Bay used 7 or fewer services while in the area.

\section{Services at Colter Bay}

Respondents were asked what services or facilities they liked best at Colter Bay. Results for respondents' first answer are below in Table 7 in descending order of frequencies. Eleven unique answers were provided. The general store was identified by a plurality of respondents $(21 \%)$ while the Visitor Center was given by about one in six respondents (16\%). The Indian Arts Museum ranked $6^{\text {th }}$ out of the 11 answers $(10 \%)$.

Factor analysis of services at Colter Bay was conducted to determine if patterns existed in the data on services used while at Colter Bay. A principal components analysis was performed on 12 services, yielding an explained variance of $51.4 \%$. Three factors emerged with eight values of 1 or greater. The results show that four services hung together for factor 1 which we named the Visitor Services factor: visitor center, restrooms, general store, and Museum (Table 7). This outcome makes sense considering that the visitor center, restrooms, and Museum are all located in the same building.

Table 7. Services or facilities liked best.

\begin{tabular}{|c|c|c|c|}
\hline 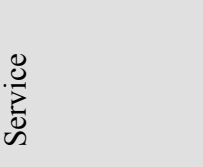 & 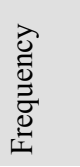 & 믈 & 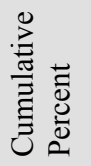 \\
\hline General store & 40 & 21.1 & 21.1 \\
\hline Visitor Center & 31 & 16.3 & 37.4 \\
\hline Showers & 30 & 15.8 & 53.2 \\
\hline Campsite & 24 & 12.6 & 65.8 \\
\hline Restaurant & 22 & 11.6 & 77.4 \\
\hline $\begin{array}{l}\text { Indian Arts } \\
\text { Museum }\end{array}$ & 19 & 10.0 & 87.4 \\
\hline Marina & 17 & 8.9 & 96.3 \\
\hline Lake & 3 & 1.6 & 97.9 \\
\hline Trails & 3 & 1.6 & 99.5 \\
\hline Amphitheatre & 1 & .5 & 100.0 \\
\hline Total & 190 & 100.0 & \\
\hline
\end{tabular}

General Store is nearby and provides many of the same services found at the Visitor Center. Factor 2: Overnight Services, has only two variables occurring together-lodging and laundry. Factor 3: Developed Recreation, the weakest factor, has only two services hanging together - the corral and marina (Table 8).
Table 8. Rotated Component Matrix of services.

\begin{tabular}{|l|l|l|l|}
\hline \multirow{2}{*}{} & \multicolumn{3}{|l|}{ Component } \\
\cline { 2 - 4 } & $\mathbf{1}$ & $\mathbf{2}$ & $\mathbf{3}$ \\
\hline Visitor Center & .772 & & \\
Restrooms & .749 & & \\
General Store & .531 & & \\
Indian Arts & .501 & & \\
Museum & & & \\
Trails & & & \\
Ranger Program & & & \\
Picnic Facility & & & \\
Laundry & & .977 & \\
Lodging & & .977 & \\
Marina & & & .706 \\
Corral & & & .670 \\
Restaurant & & & \\
\hline
\end{tabular}

\section{Colter Bay Visitor Center Services}

Respondents were asked which of seven services they used at Colter Bay during their trip; they were to check one or more services. A total of 543 respondents said they used one or more of the services for a total of 1,476 Colter Bay services used (mean = 2.7 services per respondent). Frequency of use in descending order is shown below:

$\begin{array}{llr} & \text { Services used at Colter Bay } \\ \text { - } & \text { Restroom } & 76.4 \% \\ \text { - } & \text { Information Counter } & 70.9 \% \\ \text { - } & \text { Bookstore } & 55.1 \% \\ \text { - } & \text { Museum } & 36.5 \% \\ \text { - } & \text { Ranger Program } & 20.8 \% \\ \text { - } & \text { Permit Office } & 9.8 \% \\ \text { - } & \text { Water Station } & 2.4 \%\end{array}$

First visitors were more likely than repeat visitors to use the information counter, the restroom, and the water station while repeat visitors were more likely than first-time visitors to use: the permit office, the bookstore, the museum, and ranger program. Among those who were first-time visitors, 33\% went to the museum, but among the repeat visitors, $40 \%$ went to the museum (Table 9).

Less important reasons for choosing to stay at Colter Bay were the museum, boating opportunities, traditions and fishing. Another reason volunteered frequently by the survey participants was the area's proximity to Yellowstone National Park. Many indicated that the Colter Bay area was the most 
centrally located area to visit both Yellowstone and Grand Teton.

Table 9. Colter Bay services by first trip to Colter Bay.

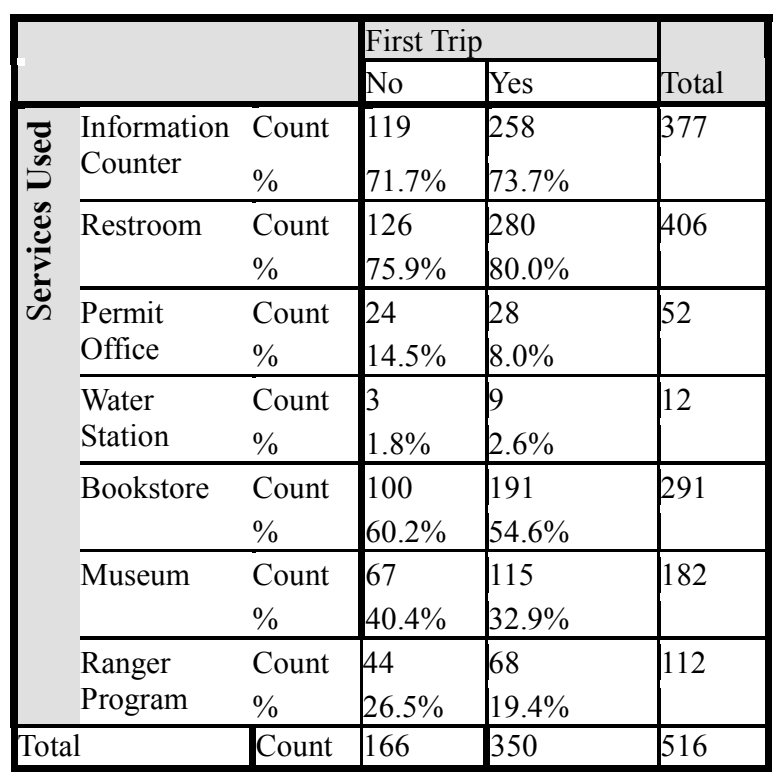

Table 10. Visitors' selection for Reason for Choosing [to

\begin{tabular}{|l|l|l|l|}
\hline $\begin{array}{l}\text { Reasons for Choosing } \\
\text { Colter Bay }\end{array}$ & $\mathrm{N}$ & Mean & $\begin{array}{l}\text { Std. } \\
\text { Deviation }\end{array}$ \\
\hline Experiencing Nature & 481 & 1.94 & .246 \\
Wildlife Viewing & 481 & 1.91 & .280 \\
Experiencing & 470 & 1.90 & .303 \\
Wilderness & & & \\
Rustic Nature & 466 & 1.86 & .347 \\
For the Lake & 482 & 1.85 & .361 \\
Peace and Quiet & 469 & 1.83 & .378 \\
Marked Trails & 453 & 1.79 & .404 \\
Accessible & 496 & 1.75 & .432 \\
Family Friendly & 465 & 1.71 & .454 \\
Not As Crowded & 460 & 1.70 & .457 \\
Campgrounds & 462 & 1.62 & .486 \\
Museum & 450 & 1.39 & .488 \\
Boating & 443 & 1.37 & .485 \\
Family Tradition & 459 & 1.29 & .454 \\
Fishing & 434 & 1.28 & .451 \\
& & & \\
\hline
\end{tabular}

visit] Colter Bay on this Trip to GTNP.

Respondents were asked to indicate which factors they thought were important in their decision to visit Colter Bay (Table 10). Not important was coded as 1 and important was coded as 2 . The results confirm the findings of the recreational preferences of the Colter Bay visitors. Experiencing undisturbed nature and viewing wildlife were the most important reasons for visiting the Colter Bay area, with over $90 \%$ of respondent rating them as an important reason. Less important reasons for choosing to stay at Colter Bay were the museum, boating opportunities, traditions and fishing. Another reason volunteered frequently by the survey participants was the area's proximity to Yellowstone National Park. Many indicated that the Colter Bay area was the most centrally located area to visit both Yellowstone and Grand Teton.

Table 11. Aware of Indian Arts Museum prior to trip.

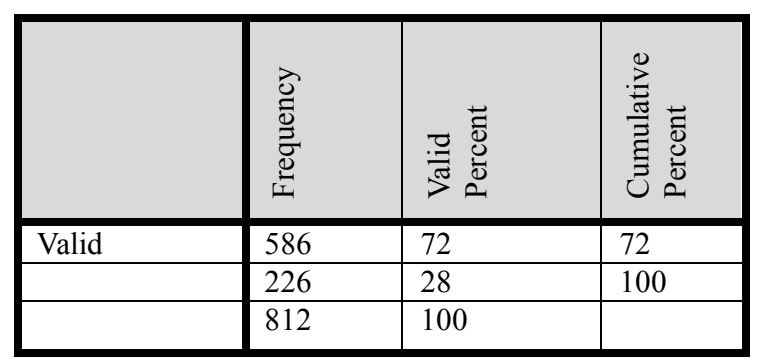

\section{Indian Arts Museum Results}

A key component of the research project related to the Indian Arts Museum in the Colter Bay Visitor Center. First, respondents were asked if they were aware of the Museum before their trip began. Only 28\% indicated that they were aware of the Museum (Table 11). However, some $80 \%$ of respondents who had planned to visit the Museum did in fact visit the Museum.

Researchers wanted to know if there was a relationship between whether it was the respondents' first trip or a repeat trip to the Park and respondents' awareness of the Museum. Among those who were on their first trip to the Park, only $20 \%$ knew about the Museum while $56 \%$ of the repeat visitors knew about the Museum, a difference of about $35 \%$. This suggests that a large number of respondents only learn about the Museum once in the Park. Once visitors actually arrive at Colter Bay approximately 50\% 0f the actually visit the museum (Table 12).

Table 12. Percent of visitors to Colter Bay who visited the Indian Arts Museum.

\begin{tabular}{|ll|l|l|l|}
\hline & Frequency & Valid Percent & $\begin{array}{l}\text { Cumulative } \\
\text { Percent }\end{array}$ \\
\hline \multirow{3}{*}{ Valid } & No & 276 & 49.2 & 49.2 \\
& Yes & 285 & 50.8 & 100.0 \\
& Total & 561 & 100.0 & \\
\hline
\end{tabular}


For those respondents who visited the Museum during this trip, respondents were then asked if they would visit the Museum again 76 indicated they would visit it again (Table 13).

Table 13. Would visit Indian Arts Museum again.

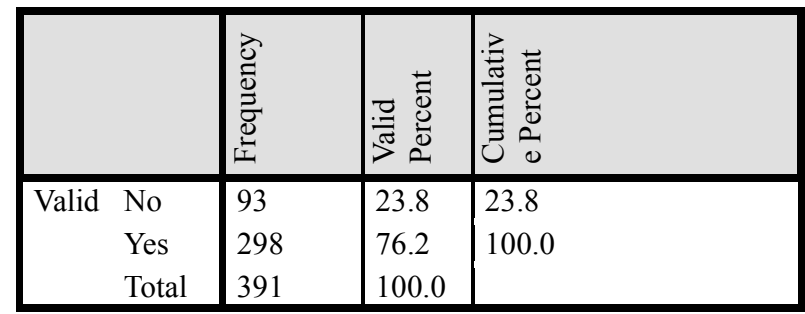

Respondents were asked that if the Indian Arts Museum at Colter Bay were discontinued or moved, what exhibit topics they would prefer to see in the Museum (Table 14). Almost two-thirds (65.7\%) of the respondents indicated that the exhibits should stay the same. Only $16 \%$ had no interest in new exhibits while $19 \%$ were preferred new exhibits.

Using crosstabulation and Chi-Square, personal factors (gender, race, age, education) showed no statistically significant relationship to the Indian Arts Museum exhibit preferences. In households with younger children (age 0 through age 12), there was a weak, statistically significant relationship $\left(\mathrm{X}^{2}=\right.$ 15.673 , df $=2$, p. $=.000 ; \mathrm{V}=.19)$ (Table 15). Respondents with children (23\%) were twice as likely to be interested in new exhibits as those without younger children $(10 \%)$.

Furthermore, respondents were asked if the Indian Arts Museum was located at the Moose Visitor Center whether they would be less likely or more likely to have visited the Museum while on their trip (Table 16). About 26\% indicated that they would have been less likely to have visited the Museum at Moose while only $12 \%$ said that they would have been more likely. The majority of $(62 \%)$ respondents were not sure about the likelihood of visiting the Museum in Moose.

Lastly, researchers wanted to know if visiting the Museum while on their trip would affect respondents' opinions about visiting the Museum if it was moved to Moose (Table 17). Those who visited the Museum (36\%) were almost three times more likely to indicate that they would be less likely (14\%) to go to the Museum if the Museum were at Moose $\left(\mathrm{X}^{2}\right.$ $=36.411, \mathrm{df}=2, \mathrm{p} .=.000, \mathrm{~V}=.26)$.

\section{Time Spent in the Indian Arts Museum}

For those visiting the Museum on this trip, researchers asked how long visitors spent in the Museum (Table 18). Answers ranged from less than 15 minutes to more than 2 hours. Some 13\% (1 in 7) indicated that they were in the Museum for less than 15 minutes. The median length of stay was 30 minutes to 60 minutes with $79 \%$ of respondents indicating that they spent about 1 hour or less in the Museum. Twenty percent indicated that they were in the Museum 1 to 2 hours while only $1 \%$ said they were in the Museum for more than 2 hours (Table 18).

Table 14. Opinion on Indian Arts Museum exhibits.

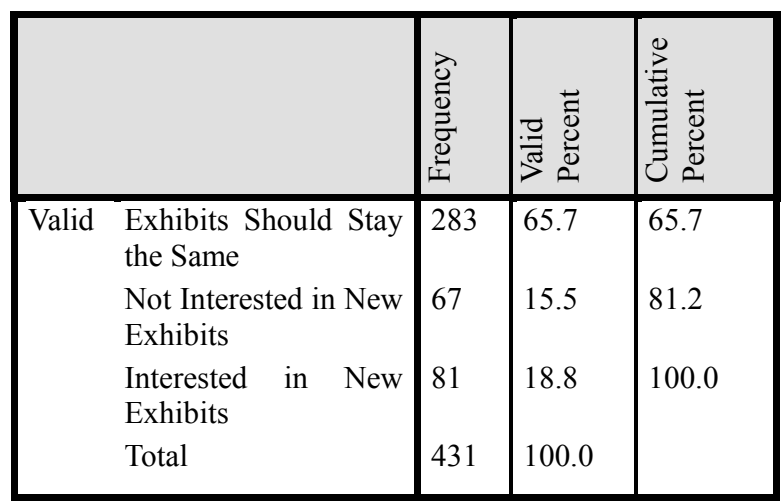

Table 15. Opinion of Museum exhibits by Children in household age 0 to 12 .

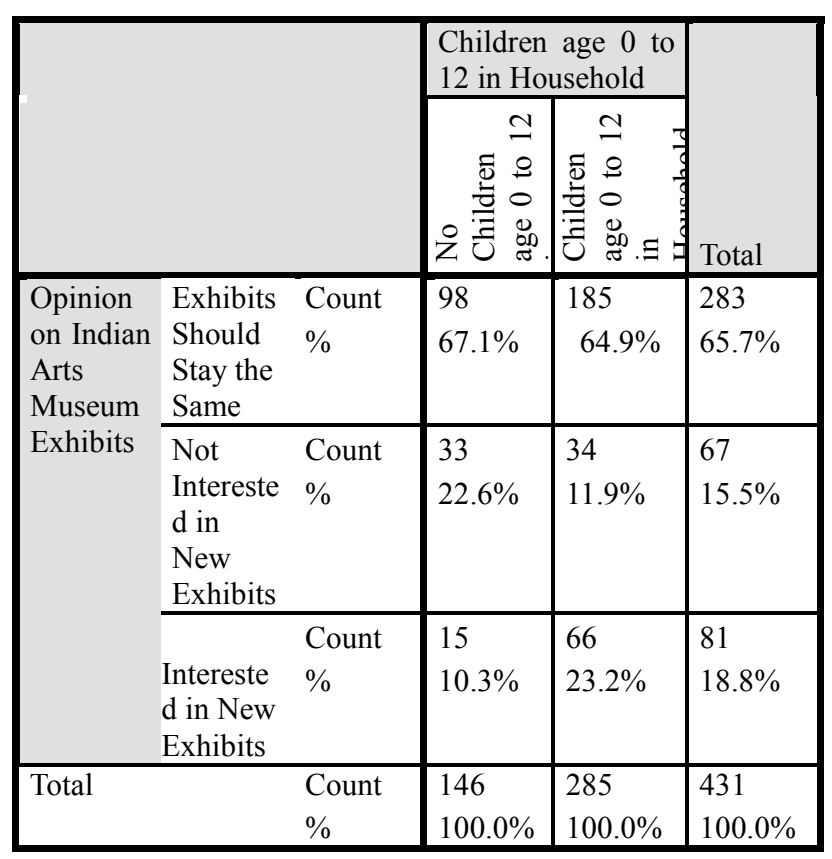

Table 16. Likelihood of visiting Museum if at Moose. 


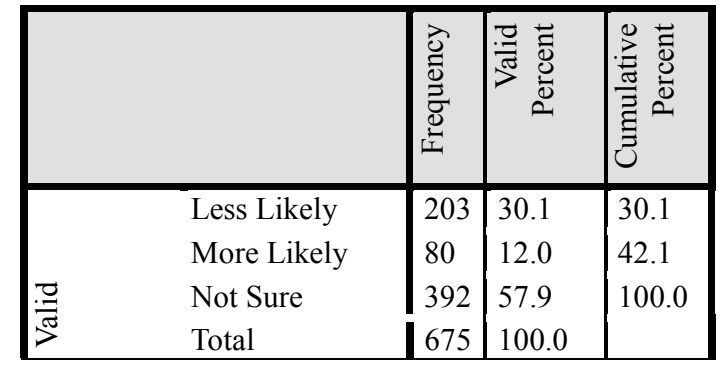

Table 17. Likelihood of visiting Museum if at Moose by Visit Museum on trip.

\begin{tabular}{|lll|r|r|r|}
\hline & & & \multicolumn{2}{|c|}{ Visit Museum } & \\
\cline { 3 - 5 } & & No & \multicolumn{1}{c|}{ Yes } & \multicolumn{1}{c|}{ Total } \\
\hline $\begin{array}{l}\text { Likelihood } \\
\text { of Visiting } \\
\text { Museum if } \\
\text { at Moose }\end{array}$ & Less & Count & 35 & 101 & 136 \\
& More & $\%$ & $14.3 \%$ & $36.2 \%$ & $26.0 \%$ \\
& Likely & $\%$ & $16.3 \%$ & $7.5 \%$ & $11.6 \%$ \\
\cline { 2 - 5 } & Not & Count & 170 & 157 & 327 \\
& Sure & $\%$ & $69.4 \%$ & $56.3 \%$ & $62.4 \%$ \\
\hline Total & & Count & 245 & 279 & 524 \\
& & $\%$ & $100.0 \%$ & $100.0 \%$ & $100.0 \%$ \\
\hline
\end{tabular}

Table 18. Length of Time Spent in the Indian Arts Museum by Visitors.

\begin{tabular}{|c|c|c|c|c|}
\hline & & 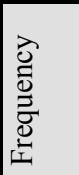 & 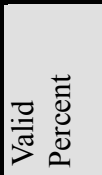 & 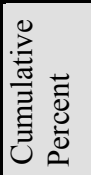 \\
\hline Valid & $\begin{array}{l}\text { Less than } 15 \text { minutes } \\
15 \text { to } 30 \text { minutes } \\
30 \text { minutes to } 1 \text { hour } \\
1 \text { to } 2 \text { hours } \\
\text { More than two } \\
\text { hours } \\
\text { Total }\end{array}$ & $\begin{array}{l}54 \\
107 \\
166 \\
83 \\
5 \\
415\end{array}$ & \begin{tabular}{|l|}
13.0 \\
25.8 \\
40.0 \\
1.2 \\
100.0
\end{tabular} & $\begin{array}{l}13.0 \\
38.8 \\
78.8 \\
98.8 \\
100.0\end{array}$ \\
\hline
\end{tabular}

A part of the Museum is the special events and programs at the Museum. These could serve to increase learning, enjoyment, and the likelihood that a respondent would visit the Museum. Respondents were asked to indicate if they were at the Museum when there was a special event or program at the Museum (Table 19). About a quarter (27\%) said that this was true. As a follow-up question, they were asked if they visited the Museum because of the special event or program. Only two individuals indicated that this was true.
Table 19. Special event or program at Indian Arts Museum during visit.

\begin{tabular}{|ll|l|l|l|}
\hline & & Frequency & $\begin{array}{l}\text { Valid } \\
\text { Percent }\end{array}$ & $\begin{array}{l}\text { Cumulative } \\
\text { Percent }\end{array}$ \\
\hline Valid & No & 75 & 73.5 & 73.5 \\
& Yes & 27 & 26.5 & 100.0 \\
& Total & 102 & 100.0 & \\
Total & & 250 & & \\
\hline
\end{tabular}

\section{Guest Artist at Museum}

Respondents were asked if they visited the Guest Artist area in the Museum during their visit to the Museum (Table 20). Only a third noted that they did visit the guest area and only about $10 \%$ said that they purchased one or more items at the guest artist area (Table 21).

Table 20. Visited guest artist at the Museum.

\begin{tabular}{|ll|l|l|l|}
\hline & Frequency & $\begin{array}{l}\text { Valid } \\
\text { Percent }\end{array}$ & $\begin{array}{l}\text { Cumulative } \\
\text { Percent }\end{array}$ \\
\hline Valid & No & 376 & 67.0 & 67.0 \\
& Yes & 185 & 33.0 & 100.0 \\
& Total & 561 & 100.0 & \\
\hline
\end{tabular}

Table 21. Made a purchase at the guest artist area.

\begin{tabular}{|ll|l|l|l|}
\hline & Frequency & Valid Percent & $\begin{array}{l}\text { Cumulative } \\
\text { Percent }\end{array}$ \\
\hline Valid & No & 509 & 90.2 & 90.2 \\
Yes & 55 & 9.8 & 100.0 \\
Total & 564 & 100.0 & \\
\hline
\end{tabular}

A resounding $76 \%$ indicated that they would visit it again (Table 22).

Table 22. Would visit Indian Arts Museum again.

\begin{tabular}{|l|l|l|l|l|}
\hline \multicolumn{2}{|l|}{} & Frequency & $\begin{array}{l}\text { Valid } \\
\text { Percent }\end{array}$ & $\begin{array}{l}\text { Cumulative } \\
\text { Percent }\end{array}$ \\
\hline Valid & No & 83 & 23.8 & \\
\hline & Yes & 201 & 76.2 & 100 \\
\hline & Total & 107 & 100 & \\
\hline
\end{tabular}

\section{Indian Arts Museum Interviews}

During the summer, 2010, two researchers were stationed at the Colter Bay Visitor's Center (Indian Arts Museum). They interviewed selected individuals as they were exiting the Museum one-half 
day weekly. The following represents a summary of responses to the open-ended questions.

First, respondents were asked what they hoped to learn in the Museum. Answers were categorized into 6 categories listed below in descending order of frequency. The plurality of responses was centered on learning about Indian culture. Several respondents simply indicated that they had no specific expectations. A few said that they wanted to see how Indians made art and objects.

- Indian culture

- No expectations

- Others

- How they made art and objects

- What was there

- Meet Indians

Respondents were asked about which exhibit they liked most. Responses were categorized and are listed by category in descending order of mention. Bead work was identified by more respondents as the exhibit they most liked more than any other exhibit. Moccasins and weaponry were the second and third most identified, followed by the guest artist and clothing.

1. Bead work

2. Moccasins

3. Weaponry/warfare

4. Guest artist

5. Clothing

Last, respondents were asked which part of the Museum was most important for people to see. Answers were grouped into six unique categories. By far the "whole thing" was the most common response.

1. Whole thing

2. History

3. How they lived

4. Art work

5. Teepee

6. Artists

\section{Moose Results}

During one of every three days, the research assistants spent time at the Moose Visitor Center area interviewing individuals outside of the Center. Respondents were asked questions during the interview, which took about 10 minutes to complete, that paralleled the ones being asked at Colter Bay. Data were collected on 133 individuals. Demographic characteristics were not significantly different from those collected in the at home survey and in the Colter Bay interviews.
Trip characteristics were different in several ways for visitors interviewed at Moose. The visitors at the Moose visitor center were more likely to have entered from the south through Jackson and their median length of stay was three days, while at Colter Bay it was 4 days. They were also less likely to be staying overnight in the park. Only $56 \%$ were planning to utilize lodging in the park as compared to $80 \%$ in the Colter Bay interviews. Just over half indicated Grand Teton was their most important destination, while at Colter Bay only $30 \%$ believed GRTE was their most important destination on this trip. While only $43 \%$ said it was their first trip to GRTE, $65 \%$ said it was their first stop at Moose.

\section{Moose Museum Questions}

Respondents were asked if the Indian Arts Museum had been at Moose, would they have visited the Museum (Table 23). Over $82 \%$ indicated that they would have visited the Museum if it was located at Moose as compared to only approximately $50 \%$ who actually visited at Colter Bay. As a follow-up question, respondents were asked if they had visited the Indian Arts Museum during this trip (Table 24). Fifty-percent noted that they had visited the Museum while 45\% said that they had not. An additional 7 individuals indicated that they were planning to go to the Museum, but had not yet done so on the trip. Moreover, some $70 \%$ said that they had visited the Colter Bay Visitor Center in which the Museum is located (Table 25). This suggests that $20 \%$ of the respondents went into the Colter Bay Visitor Center, but did not go into the Museum while in the Visitor Center.

Table 23. Would have visited Museum if located at Moose.

\begin{tabular}{|ll|l|l|l|}
\hline & Frequency & $\begin{array}{l}\text { Valid } \\
\text { Percent }\end{array}$ & $\begin{array}{l}\text { Cumulative } \\
\text { Percent }\end{array}$ \\
\hline Valid & No & 10 & 17.9 & 17.9 \\
& Yes & 46 & 82.1 & 100.0 \\
& Total & 56 & 100.0 & \\
& & & \\
\hline
\end{tabular}

Table 24. Visited Indian Arts Museum.

\begin{tabular}{|ll|l|l|l|}
\hline & Frequency & $\begin{array}{l}\text { Valid } \\
\text { Percent }\end{array}$ & $\begin{array}{l}\text { Cumulative } \\
\text { Percent }\end{array}$ \\
\hline Valid & No & 22 & 44.9 & 44.9 \\
& Yes & 27 & 55.1 & 100.0 \\
& Total & 49 & 100.0 & \\
\hline
\end{tabular}

Table 25. Visited Colter Bay Visitor Center. 


\begin{tabular}{|l|l|l|l|}
\hline & Frequency & $\begin{array}{l}\text { Valid } \\
\text { Percent }\end{array}$ & $\begin{array}{l}\text { Cumulative } \\
\text { Percent }\end{array}$ \\
\hline Valid No & 16 & 30.2 & 30.2 \\
Yes & 37 & 69.8 & 100.0 \\
Total & 53 & 100.0 & \\
& & & \\
\hline
\end{tabular}

\section{Summary and Conclusions}

- The results of the three surveys are similar. The demographic characteristics contain no surprises. The respondents were well educated, about half were traveling with children. About half were repeat visitors to GRTE. Half were between 40 and 60 years of age. About $20 \%$ were day visitors and $80 \%$ were planning to stay overnight in the park.

- About $83 \%$ of Colter Bay visitors visited the Visitor Center while only about $16 \%$ did not.

- Services used at Colter Bay Visitor Center indicated the most important was restrooms (76\%) followed closely by information counter (71\%) and bookstore (55\%). The museum was indicated in $36 \%$ of cases and ranger programs in $21 \%$ of cases. The visitor center was very important to the visitors to Colter Bay. They indicated they used a mean of 2.7 of the services offered. The median time spent in the museum was $30-60$ minutes with only $12 \%$ staying less than 15 minutes.

- Of all the recreational activities available at Colter Bay the Museum ranked $10^{\text {th }}$ in importance value to the visitors. Observing wildlife was first with observing nature a close second. The Museum's mean rating of 2.9 is halfway between the scale values of 1 to 5 with 1 being very unimportant and 5 being very important; thus the mean suggests that the Museum's importance level is, on average, neither important nor unimportant to these visitors.

- While a great many visitors go to the Indian Arts Museum, going to the Museum ranks $10^{\text {th }}$ among the activities listed. The top five ranked activities all have to do with outdoor activities, such as wildlife and nature observation. Of those having children, there was a desire to have new exhibits. Thus, we recommend that NPS strongly consider rotating Indian Arts exhibits, and increasing exhibitry concerning natural history of the Colter Bay area. The Museum was ranked $6^{\text {th }}$ out of 11 activities and moreover if the Museum were moved, total visitation to Colter Bay would not be impacted. Only 40 percent of the respondents who visited Colter Bay went to the Museum. The average person was interviewed about two-thirds through in their planned number of days to stay in the park. This means that going to the Museum was low on priority. Also, there was only a slight increase in Museum visitation among those who were in the Park for one day.

- A high percentage (80\%) of the visitors to Moose indicated they would visit Indian arts exhibitry if it were in the Moose Visitor Center. This indicates a potentially higher rate of visitation than currently exists at Colter Bay.

- By far the most popular exhibit was the bead work. If only part of the exhibits are utilized, the most important to bring back are the bead work, moccasins, and war implements. If the exhibits are revised, an improved teepee exhibit may satisfy the general interest in Indian culture and teepees.

- Based on comments and observation, the Museum benefits greatly from being in a Visitor Center. If the Museum were separated, it is the researchers' opinion there would be much less visitation to the Museum.

- Consider rearranging the exhibits with the bead work on the first floor with a teepee visible from the top floor which may serve to draw people downstairs. 